\title{
HUBUNGAN TINGKAT SERANGAN ULAT KIPAT (CRICULA TRIFENESTRATA) TERHADAP HASIL METE
}

\author{
Rina Siswanti ${ }^{1}$ ), Supriyadi ${ }^{2}$ ), Subagiya ${ }^{2}$ ), \\ 1) Mahasiswa S1 Program Studi Agroteknologi, Fakultas Pertanian, Universitas Sebelas Maret \\ 2) Staf Dosen Program Studi Agroteknologi, Fakultas Pertanian, Universitas Sebelas Maret \\ Kontak Penulis: rinasiswanti17@gmail.com
}

\begin{abstract}
Cricula trifenestrata Helfer (Lepidoptera;Saturniidae) are insect pest of avocado, walnuts, and cashews. C. trifenestrata is most destructive insect pest of cashews, but there is no serious control by farmers. The questions about the effect of $C$. trifenestrata to cashew's yield. This study aimed to determine the correlation and regression attack degree of $\mathrm{C}$. trifenestrata to the number of flowers and seeds produced by cashew. Research was conducted by a survey of 30 cashew plants with 6 samples unit at each plant. The parameters observed in this study were plant varieties, plant age, time appears caterpillar, caterpillar number, the attack rate, days to flowering, the number of bunches, flower, and seed. The data were analysed by the correlation and regression analysis. The results showed a positive correlation between the degree of caterpillar attacks to number of flowers and seeds. Increasing degree of attacks may increase the number of flowers and seeds.
\end{abstract}

Keywords: correlation, regression, flowering

AGROTECHNOLOGY RESEARCH JOURNAL

Siswanti R, Supriyadi, Subagiya. 2017. Correlation between damage plant by silkworm Cricula trifenestrata to cashew yield. Agrotech Res J 1(1): 21-27.

Siswanti R, Supriyadi, Subagiya. 2017. Hubungan tingkat serangan ulat kipat (Cricula trifenestrata Helfer) terhadap hasil mete. Agrotech Res J 1(1): 21-27.

\section{PENDAHULUAN}

Indonesia merupakan salah satu negara pengekspor mete. Listyati dan Sudjarmoko (2011) menyatakan bahwa Indonesia adalah negara produsen mete keenam dunia setelah negara India, Vietnam, Afrika Barat, Afrika Timur, dan Brasil. Mete memiliki potensi yang besar untuk dikembangkan di Indonesia, utamanya dalam memenuhi kebutuhan ekspor. Jawa Tengah merupakan daerah penghasil mete tertinggi kedua setelah Sumatera Utara (Ditjenbun 2015). Wonogiri merupakan salah satu daerah produksi mete di Jawa Tengah dengan produktivitas yang selalu meningkat dari tahun 2008-2013 yaitu sebesar 10.365 ton (BPS 2014), hal ini menunjukkan bahwa produksi mete di Wonogiri memiliki potensi yang besar untuk terus dikembangkan.

Tanaman mete dibudidayakan dengan menggunakan bahan tanam berupa bahan tanam vegetative maupun generative. Tanaman mete akan tumbuh dengan baik apabila bahan tanam berasal dari ukuran benih yang besar karena penyerapan unsur hara lebih optimal (Hammed et al. 2011). Pemeliharaan pada tanaman mete dapat berupa pemupukan dan pemberantasan hama penyakit (Daras dan Pitono 2006).

Serangga hama yang terdapat pada tanaman mete umumnya adalah serangga fitofag yang termasuk dalam ordo hemiptera, Coleoptera, Diptera dan Lepidoptera. serangga tersebut yaitu Heleopeltis spp, Sanurus indecora, Plocaderus Ferrugineus, Anastrepha fraterculus Weidman, dan Cricula trifenestrata Helfer (Soesanthy dan Trisawa 2011). Plocaederus ferrugineus adalah hama penting pada tanaman mete yang dapat mematikan tanaman

${ }^{*}$ Fak. Pertanian UNS Surakarta

JI. Ir. Sutami 36 A Surakarta dalam waktu beberapa minggu.Hama ini merusak jaringan pembuluh dan melemahkan batang hingga batang menguning, daun gugur, pengeringan ranting lalu tanaman mati (Assogwa et al. 2009).

Hama utama yang menyerang pertanaman mete di Wonogiri adalah ulat kipat (C. trifenestrata). Nassig et al. (2006) menyatakan bahwa ulat kipat merupakan spesies yang terdapat di negara Filipina, India, dan Indonesia, serta merupakan spesies endemik pada daerah Sumatera, Jawa, dan Sulawesi. Menurut Rono et al. (2008), stadium larva pada ulat kipat terbagi atas 5 instar dengan kemampuan memakan paling tinggi adalah pada instar ketigaa.

Stadium larva pada instar ketiga mengalami pertumbuhan yang cepat yaitu dapat mencapai 2 kali lipat dari instar kedua. Setelah fase ulat lalu $C$. trifenestrata membentuk pupa yang terbentuk oleh kokon. Kokon ulat kipat tersusun satu lapis yang memiliki struktur anyaman dengan lubang yang besar (Chen et al. 2012)

Soesanthy dan Trisawa (2011) menyatakan bahwa Seekor ulat kipat selama masa perkembangannya dapat mengkonsumsi daun tanaman mete sebanyak 63 lembar. Menurut Karmawati (2008), ulat kecil memakan daun yang masih muda dari bagian bawah, secara bergerombol dan bekas serangan terlihat seperti sobekan-sobekan tidak teratur pada pinggiran daun. Serangan ulat yang lebih besar dapat menghabiskan seluruh helainya, tinggal tulang daun saja. Adanya populasi ulat yang tinggi maka seluruh daun dalam areal yang luas akan gundul, tinggal ranting-ranting saja.

Berbeda dengan di negara tropis $C$. trifenetrata pada daerah subtropis aktif sepanjang tahun kecuali pada bulan Mei. Tingkat serangan larva $C$. trifenestrata berbeda-beda tergantung pada musim saat ulat 
menyerang. Ulat mampu menyerang dengan tingkat kerusakan pada tanaman alpukat sekitar $18,42 \%$ pada saat musim gugur dan musim dingin, sedangkan tingkat kerusakan dapat mencapai $100 \%$ pada bulan Desember sampai Januari (Ahmed et al. 2012)

Kemampuan ulat kipat dalam menyerang tanaman mete sangat tinggi, namun belum ada pengendalian secara serius dari petani. Kondisi tersebut menimbulkan pertanyaan mengenai pengaruh serangan ulat kipat terhadap hasil tanaman mete. Penelitian ini bertujuan untuk mengetahui korelasi tingkat serangan ulat kipat (C. trifenestrata) terhadap hasil mete yang dilihat dari jumlah bunga dan jumlah biji yang dihasilkan tanaman mete.

\section{BAHAN DAN METODE}

Penelitian ini dilaksanakan dengan survei pada bulan Februari-Oktober 2016 bertempat di dusun Dawungan, Kelurahan Dawungan, Kecamatan Jatiroto, Kabupaten Wonogiri.Penentuan sampel dilaksanakan dengan teknik purposive sampling yaitu memilih 30 tanaman mete dengan pengelompokan berdasarkan tingkat serangan musim sebelumnya dengan kisaran umur 5-30 tahun. Sampel yang digunakan berjumlah 30 tanaman dengan 6 unit sampel pada setiap tanaman, sehingga terdapat 180 unit sampel. Unit sampel yang digunakan berupa pucuk tanaman. Pengumpulan data dengan metode wawancara dan observasi. Parameter yang diamati meliputi varietas tanaman, umur tanaman, waktu muncul ulat, jumlah ulat, tingkat serangan, waktu muncul bunga, jumlah tandan bunga, jumlah bunga, dan jumlah biji. Pengolahan data menggunakan analisis korelasi regresi.

\section{HASIL DAN PEMBAHASAN}

\section{Kondisi umum lokasi penelitian}

Lokasi peneitian berada di Desa Dawungan, Kecamatan Jatiroto, Kabupaten Wonogiri, Provinsi Jawa Tengah. Kabupaten Wonogiri memiliki luas wilayah 182.236,02 hektar yang terletak pada $7^{\circ} 32^{\prime} \mathrm{LU}$

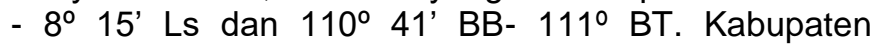
wonogiri secara topografi memiliki kemiringan $30^{\circ}$ dengan terdapat dataran rendah dan dataran tinggi. Penggunaan tanah untuk lahan pertanian di kabupaten wonogiri adalah sebesar $69 \%$ dari luas tanah atau 125,577 ha. Penggunaan lahan pertanian paling tinggi yaitu tegal sebesar $48,7 \%$. Lahan tegal digunakan untuk tanaman perkebunan. Tanaman perkebunan yang terdapat di Wonogiri antara lain tanaman mete, cengkeh, kelapa, melinjo, jarak pagar, dan lain-lain. Penggunaan lahan untuk tanaman mete adalah sebesar 20.652 ha yang tersebar pada 25 kecamatan. Lahan terluas untuk tanaman mete adalah di Kecamatan Jatiroto yaitu sebesar 3.739 ha dan terendah di Kecamatan Karangtengah yaitu sebesar 111 ha.

\section{Tingkat serangan ulat}

Tanaman yang terserang pada pengamatan pertama yaitu tanaman dengan tingkat serangan ratarata tertinggi yaitu sebesar $72,64 \%$. Tingkat serangan terendah terdapat pada pengamatan kedua yaitu sebesar $13,51 \%$ lalu meningkat pada pengamatan ketiga yaitu sebesar $15,13 \%$, pengamatan keempat yaitu sebesar $20,306 \%$, pengamatan ke 5 yaitu sebesar $29,89 \%$ hingga pengamatan ke enam yaitu sebesar $30,275 \%$ (Gambar 1). Tingkat serangan ulat diduga tidak dipengaruhi oleh jumlah ulat yang terdapat pada setiap unit sampel, tetapi dipengaruhi oleh penyebaran ulat dan daya makan ulat.

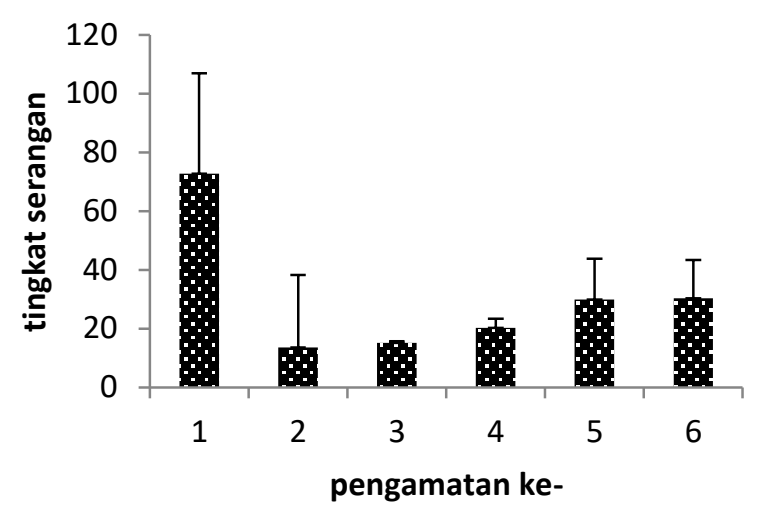

Gambar 1 Histogram tingkat serangan ulat pada berbagai pengamatan

Hasil Pengamatan menunjukkan pada sampel 1 penyebaran ulat merata yaitu terdapat pada semua unit sampel dengan jumlah ulat terbanyak yaitu 19 . Pada sampel 9 dan 15 terdapat 4 unit sampel terserang, sampel $19,21,28$, dan 30 terdapat 3 unit sampel terserang, sampel 22 dan 27 terdapat 2 sampel yang terserang, dan sampel 2, 14, dan 20 hanya 1 unit sampel yang terserang. Jumlah rata-rata ulat tertinggi yang menyerang pucuk adalah pada sampel 9 yaitu terdapat 12 ulat, sedangkan rata-rata terendah adalah pada sampel 22 yaitu 0,5 (Tabel 1). Variasi jumlah ulat dipengaruhi oleh fase ulat Fase awal ulat yaitu pada instar I dan II ulat cenderung berkoloni dengan jumlah ulat yang lebih banyak dibandingkan dengan instar berikutnya.

Tabel 1 Jumlah ulat pada tiap unit sampel tanaman terserang

\begin{tabular}{lrrrrrrr}
\hline Sampel & \multicolumn{9}{c}{ Jumlah ulat tiap unit sampel } & $\begin{array}{c}\text { Rata- } \\
\text { rata }\end{array}$ \\
& 1 & 2 & 3 & 4 & 5 & 6 & \\
\hline 1 & 2 & 19 & 7 & 7 & 4 & 1 & 6,67 \\
2 & 46 & 0 & 0 & 0 & 0 & 0 & 7,67 \\
9 & 12 & 30 & 0 & 0 & 21 & 9 & 12,00 \\
14 & 0 & 0 & 0 & 0 & 29 & 0 & 4,83 \\
15 & 11 & 0 & 3 & 0 & 2 & 3 & 3,17 \\
19 & 3 & 2 & 22 & 0 & 0 & 0 & 4,50 \\
20 & 0 & 10 & 0 & 0 & 0 & 0 & 1,67 \\
21 & 0 & 14 & 9 & 0 & 0 & 7 & 5,00 \\
22 & 2 & 1 & 0 & 0 & 0 & 0 & 0,50 \\
27 & 13 & 0 & 0 & 0 & 6 & 0 & 3,17 \\
28 & 0 & 0 & 10 & 3 & 12 & 0 & \\
& & & & 3 & & & 9,17 \\
30 & 2 & 5 & 0 & 0 & 40 & 0 & 7,83 \\
\hline \multicolumn{6}{c}{ Rata-rata } \\
\hline \multicolumn{7}{c}{}
\end{tabular}


Jumlah daun termakan tertinggi adalah 5,5 yaitu pada tanaman dengan jumlah ulat rata-rata 6,67 . Jumlah daun termakan terendah adalah 0,3 yaitu pada jumlah ulat rata-rata 0,5 . Jumlah ulat rata-rata tertinggi adalah pada sampel 9, tetapi jumlah daun termakan hanya 4,5 (Gambar 2), hal ini menunjukkan bahwa jumlah ulat tidak mempengaruhi jumlah daun yang termakan. Jumlah daun termakan diduga dipengaruhi oleh daya makan dari ulat. Daya makan ulat dapat dipengaruhi oleh fase ulat. Amin et al. (2008) menyatakan bahwa ulat pada instar I memiliki kemampuan memakan sebanyak 0,5 gram, 1,2 gram pada instar II, 22,8 gram pada instar III, 8,5 gram pada instar IV, dan 16,4 gram pada instar V.

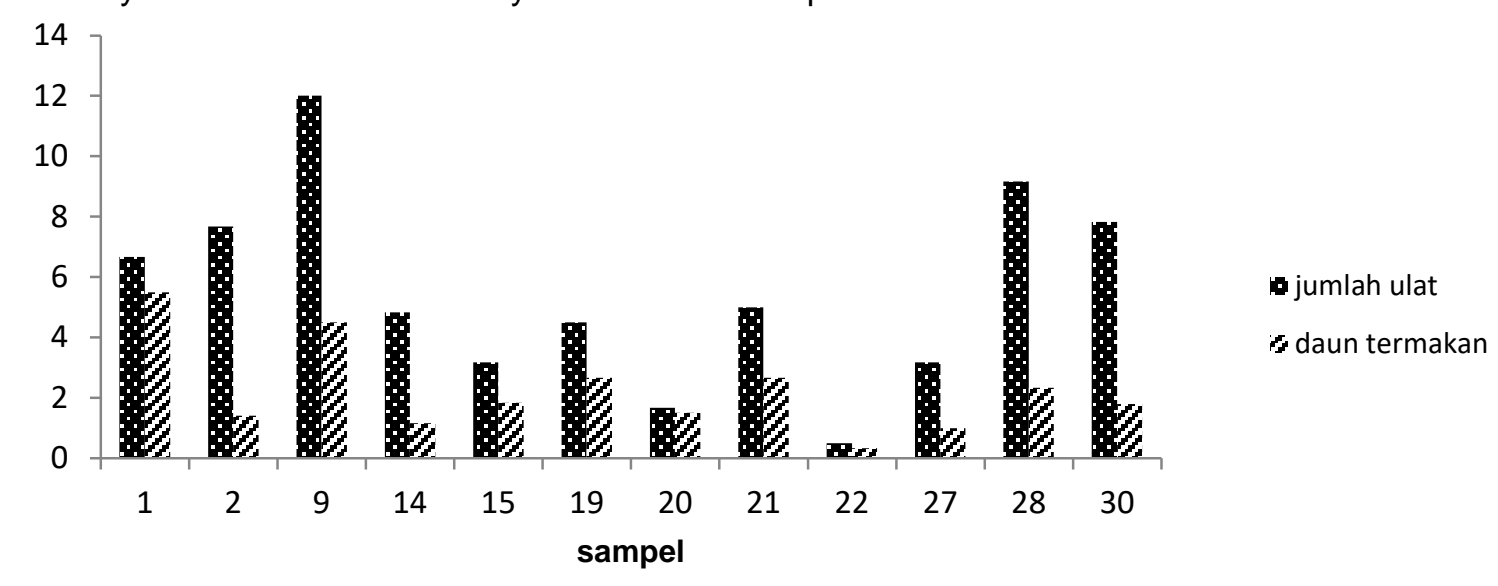

Gambar 2 Histogram hubungan jumlah ulat rata-rata dengan jumlah daun termakan

Jumlah tanaman yang terserang ulat Cricula trifenestrata pada saat pengamatan sangat rendah yaitu tidak mencapai $50 \%$ dari jumlah sampel. Serangan ulat rendah dapat disebabkan karena kondisi lingkungan (faktor abiotik) dan faktor biotik yang tidak sesuai dengan pertumbuhan dan perkembangan ulat. Ulat biasa menyerang pada akhir musim penghujan dan awal musim kemarau, namun periode ini pada musim kemarau curah hujan tinggi yang menyebabkan kondisi lingkungan tidak sesuai. Curah hujan di Kecamatan Jatiroto pada bulan januari-Oktober tergolong menengah-tinggi. Curah hujan berkisar 100-453 $\mathrm{mm} / \mathrm{bulan}$. Ulat muncul pada bulan Mei, sedangkan pada bulan tersebut curah hujan tergolong tinggi yaitu $367 \mathrm{~mm} / \mathrm{bulan}$. Kondisi lingkungan yang tidak mendukung yaitu suhu dan penerimaan cahaya rendah serta curah hujan tinggi. Wibowo et al. (2004) menyatakan bahwa suhu yang optimal untuk penetasan telur ulat kipat berkisar $28-29^{\circ} \mathrm{C}$, sehingga apabila suhu lebih rendah dari $28-29^{\circ} \mathrm{C}$ maka penetasan telur menjadi kurang optimal. Cahaya mendukung pertumbuhan dan perkembangan ulat kipat, khususnya pada instar awal. Larva yang baru menetas bersifat fototaksis yang akan semakin berkurang pada instar yang terakhir. Sifat fototaksis ini cenderung lebih kuat pada awal instar dan lemah menjelang tahap moulting. Curah hujan yang tinggi menyebabkan kelembaban tinggi yang dapat memacu pertumbuhan entomopatogen yang dapat menyerang ulat kipat. Flacherie merupakan salah satu penyakit yang dapat menyerang ulat $C$. trifenestrata yang disebabkan oleh virus maupun bakteri.Penyakit ini menyerang pada saat kelembaban tinggi (Tikader et al. 2014).Beauveria bassiana dapat menyerang ulat kipat apabila kelembaban tinggi yaitu $\mathrm{RH}$ lebih dari $80 \%$ (Yu-Rong 2005).
Faktor biotik yang menyebabkan rendahnya populasi ulat C. trifenestrata adalah parasitoid dan entomopatogen. Parasitoid yang dapat menyerang ulat kipat adalah Brachymeria tibialis, menurut Tikader (2012) parasitoid ini menyerang pada fase pupa. Pupa akan dimakan oleh Brachymeria tibialis dan akan membuat lubang pada pupa dimana lubang tersebut akan digunakan sebagai tempat keluarnya parasitoid yang telah dewasa. Parasitoid pada fase larva akan hidup di dalam pupa dan fase dewasa akan keluar dan berkembang diluar tubuh inangnya. Berdasarkan penelitian pada setiap kokon dari $C$. trifenestrata terdapat 10-15 parasitoid yang dapat hidup.Kemampuan menyerang dari parasitoid ini cukup tinggi yaitu dari 200 kokon terdapat 50 kokon yang terserang yaitu tingkat serangan kurang lebih $25 \%$.

\section{Waktu muncul bunga dan jumlah bunga}

Tanaman yang tidak berbunga dari 30 sampel tanaman adalah berjumlah 4 tanaman atau $13,33 \%$ dari keseluruhan sampel. Pengamatan ke enam menunjukkan presentase tanaman berbunga paling tinggi yaitu $40 \%$ dari jumlah sampel atau berjumlah 12 tanaman. Pengamatan pertama dan ketiga menunjukkan tanaman berbunga sebesar $6,67 \%$ dari jumlah sampel, pengamatan kedua sebesar $13,33 \%$ dari jumlah sampel. Pengamatan keempat tidak terdapat tanaman yang berbunga dan pada pengamatan ke 5 tanaman berbunga sebesar $20 \%$ dari sampel (Tabel 2).

Tabel 2 Persentasi sampel berbunga pada berbagai pengamatan

\begin{tabular}{lr}
\hline Pengamatan ke- & Persentasi berbunga (\%) \\
\hline 1 & 6,67 \\
2 & 13,33 \\
3 & 6,67
\end{tabular}




\begin{tabular}{lr}
4 & 0,00 \\
5 & 20,00 \\
6 & 40,00 \\
Tidak berbunga & 13,33 \\
\hline
\end{tabular}

Tingginya jumlah tangkai bunga diikuti dengan tingginya jumlah bunga. Jumlah tangkai bunga rata-rata pada semua tanaman adalah 2,5 dan jumlah bunga rata-rata adalah 14,99 . Jumlah tangkai dan bunga ratarata tertinggi adalah 27 dengan tangkai bunga rata-rata adalah 5,17 dan jumlah bunga rata-rata 30,75 ,

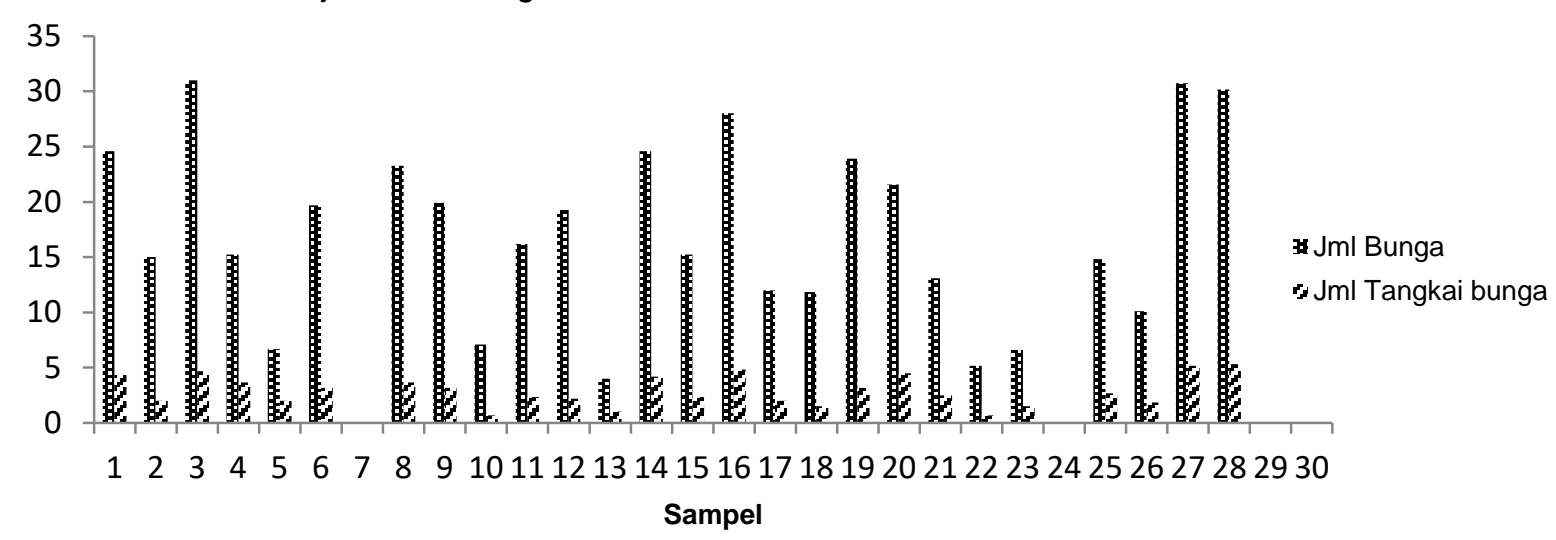

Gambar 3 Histogram hubungan jumlah tangkai bunga dan jumlah bunga setiap sampel

Jumlah bunga tertinggi adalah pada sampel dengan waktu serangan terakhir dengan tingkat serangan sebesar $30 \%$. Jumlah bunga terendah adalah pada sampel tanaman yang tidak terserang oleh ulat yaitu berjumlah 12,54 (Gambar 4). Hasil pengamatan pada jumlah bunga menunjukkan bahwa adanya serangan ulat dapat meningkatkan jumlah bunga yang dihasilkan. Histogram menunjukkan nilai error pada rata-rata jumlah bunga sangat tinggi, hal ini dikarenakan faktor iklim sangat mempengaruhi hasil pembungaan. Pada sedangakan rata-rata jumlah bunga terendah adalah pada sampel 13 dengan jumlah tangkai rata-rata 1 dan jumlah bunga rata-rata 4 . Tanaman dengan jumlah tangkai bunga dan jumlah bunga tertinggi adalah sampel yang terserang ulat dengan tingkat serangan $17 \%$, sedangkan tanaman dengan jumlah bunga terendah adalah tanaman yang tidak terserang ulat (Gambar 3).

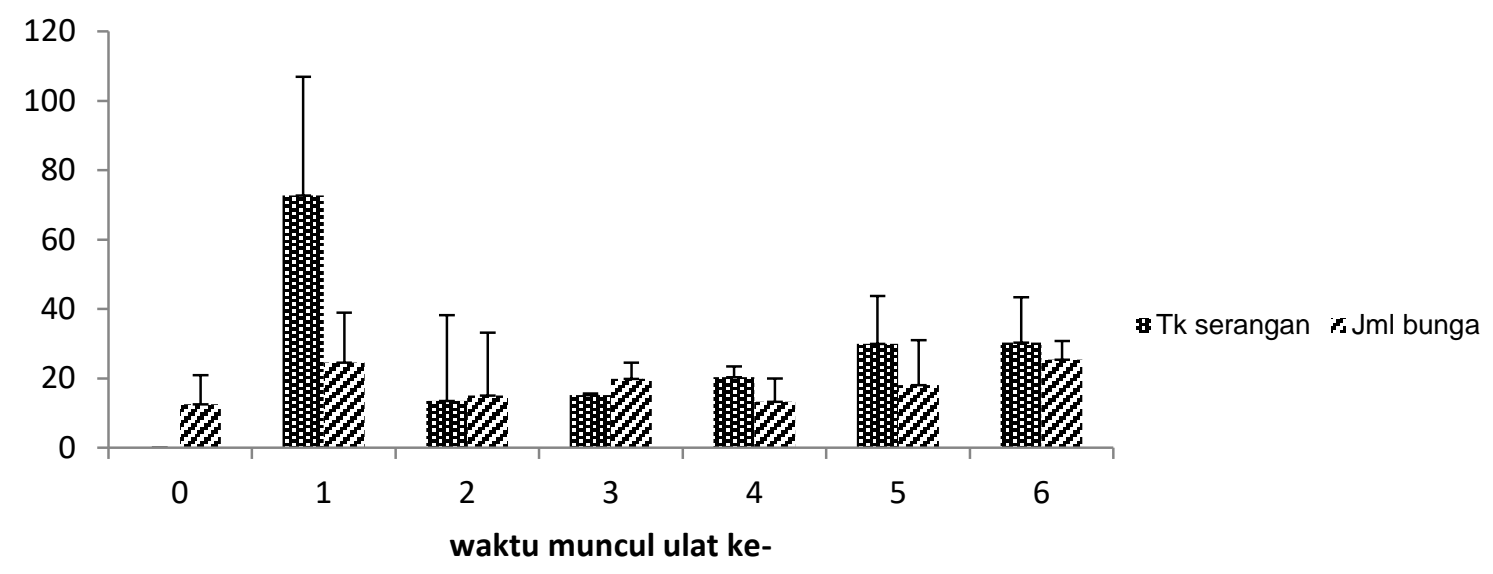

Gambar 4 Histogram hubungan Jumlah bunga dengan tingkat serangan ulat berdasarkan waktu serangan ulat

\section{Jumlah biji}

Jumlah biji tertinggi pada tanaman dengan serangan ulat $29,8 \%$ pada pengamatan ke lima dengan jumlah biji rata-rata yaitu 2,17 . Jumlah biji terendah adalah pada tanaman tidak terserang ulat yaitu sebesar 0,5(Gambar 5). Hasil pengamatan menunjukkan bahwa saat memasuki waktu pembungaan curah hujan tinggi, sehingga banyak bunga yang tidak terbentuk. Bunga muncul pada bulan Mei-Juni, sedangkan curah hujan tinggi pada bulan mei yaitu $367 \mathrm{~mm}^{-1}$ bulan dan pada bulan Juni curah hujan sedang yaitu $170 \mathrm{~mm}^{-1}$ bulan. Redaksi Trubus (2007) menyatakan bahwa jumlah hujan yang lebih banyak dari yang diinginkan dapat menyebabkan pembungaan sebagai tahap awal pembuahan tidak akan terjadi. 


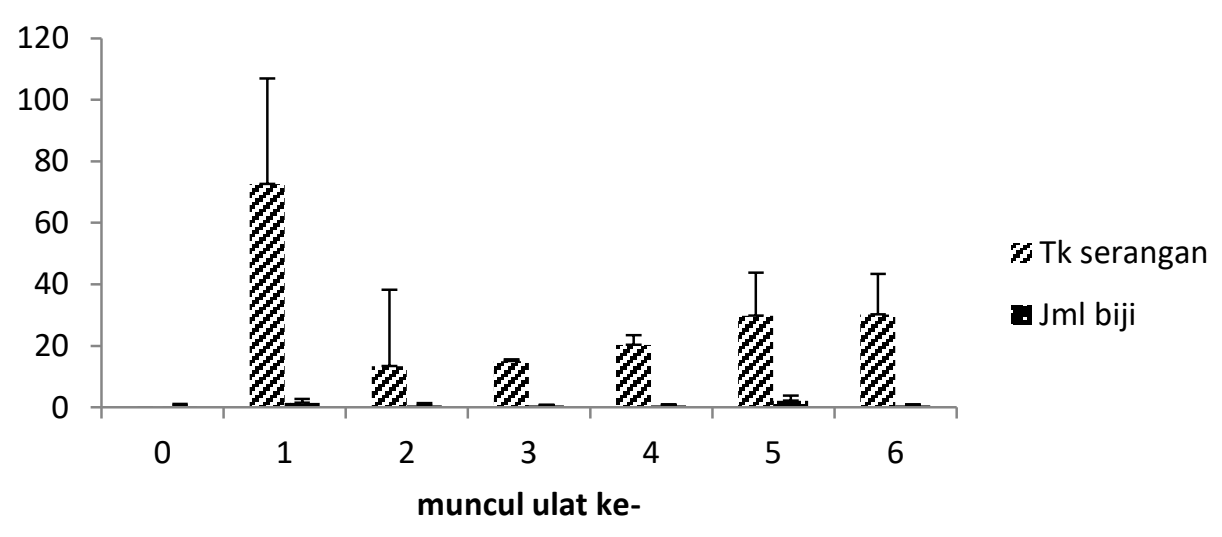

Gambar 5 Histogram hubungan jumlah biji dengan tingkat serangan

Jumlah biji pada setiap pucuk dapat dikatakan sangat rendah karena banyaknya bunga yang rontok sebelum pembuahan dan banyaknya biji yang rontok sebelum terbentuk biji yang bernas yang disebabkan karena adanya curah hujan yang tinggi. Bologoun et al. (2016) menyatakan bahwa faktor yang mempengaruhi produksi mete adalah faktor iklim berupa curah hujan, angin, dan suhu. Faktor iklim yang paling dominan dalam mempengaruhi hasil mete adalah faktor curah hujan. Curah hujan yang tidak teratur yaitu curah hujan yang terlalu intensif dan berakhirnya musim hujan tidak menentu dapat menurunkan produksi tanaman mete. Biji muncul pada bulan September-Oktober dimana curah hujan pada bulan tersebut tinggi yaitu $284 \mathrm{~mm} /$ bulan pada bulan september dan $311 \mathrm{~mm} /$ bulan pada bulan Oktober.

Thamrin et al. (2009) menyatakan bahwa penyebab kerontokan buah selain karena faktor genetik juga dapat terjadi karena adanya curah hujan yang tinggi, angin kencang, dan serangan hama penyakit. Curah hujan yang tinggi dapat menyebabkan bunga menjadi busuk dan akan mengalami kerontokan bunga sebelum terbentuk buah. Jumlah bunga yang rontok semakin tinggi maka dapat menyebabkan rendahnya jumlah biji terbentuk pada tanaman. Curah hujan juga dapat mempengaruhi mekar dan menutupnya bunga. Mekar dan menutupnya bunga dapat mempengaruhi penyerbukan, dimana keberhasilan penyerbukan dapat mempengarui pembuahan. Curah hujan yang tinggi dapat menyebabkan kelembaban lingkungan tinggi yang dapat memacu pertumbuhan patogen. Patogen yang menyerang pada buah dan biji dapat menyebabkan buah dan biji menjadi busuk dan kemudian rontok. Rendahnya jumlah biji bernas juga dapat dipengaruhi oleh penerimaan cahaya matahari oleh tanaman. Biji tidak bernas karena kurangnya penerimaan cahaya matahari, sehingga proses fotosintesis menjadi rendah. Proses fotosistesis rendah maka hasil fotosintat menjadi rendah dan penyimpanan cadangan makanan pada biji menjadi rendah.

Penyerbukan bunga merupakan faktor utama yang mempengaruhi keberhasilan pembuahan. Penyerbukan bunga dapat terjadi karena adanya bantuan dari air, angin, maupun serangga polinator. Serangga polinator lebih berpengaruh dalam penyebaran serbuk sari karena memiliki mobilitas yang tinggi dalam mencari nektar pada bunga. Aktivitas polinator dipengaruhi oleh lingkungan. Curah hujan yang tinggi menyebabkan suhu lingkungan menjadi rendah. Scaven, Nicole (2013) menyatakan bahwa perubahan suhu dapat mempengaruhi aktivitas dari serangga polinator. Suhu yang tinggi dapat memicu pertumbuhan dari serangga. Pertumbuhan yang cepat menyebabkan serangga berukuran kecil, namun lebih aktif dalam mencari nektar, sehingga serangga polinator yang berukuran kecil akan lebih intensif dalam penyebaran serbuk sari. Sebaliknya, suhu yang rendah menyebabkan pertumbuhan serangga menjadi lambat namun ukuran serangga yang besar. Serangga polinator yang berukuran besar lebih pasif daripada polinator berukuran kecil, sehingga polinator yang berukuran besar memiliki peranan yang rendah dalam penyebaran serbuk sari. Selain itu, serangga merupakan organisme berdarah panas, sehingga sangat peka terhadap perubahan suhu. Suhu lingkungan yang rendah dapat mengurangi aktivitas dari serangga, sehingga apabila suhu lingkungan rendah maka aktivitas polinator dalam mencari nektar juga rendah yang dapat mempengaruhi pada penyebaran serbuk sari.

\section{Analisis korelasi regresi}

Analisis korelasi digunakan untuk mengetahui hubungan antar 2 variabel atau lebih. Hasil analisi korelasi dapat bernilai positif maupun negatif. Hasil analisis korelasi antara waktu muncul ulat, jumlah ulat, dan tingkat serangan dengan jumlah bunga menunjukkan nilai $R$ sebesar 0,507 (Tabel 7) yang menunjukkan hubungan yang cukup kuat. Persamaan regresi untuk hubungan waktu muncul ulat, jumlah ulat, dan tingkat serangan ulat dengan jumlah bunga adalah $L N Y=2,535-0,534 X_{1}+0,053 \operatorname{Ln} X_{2}+0,160 \operatorname{Ln} X_{3}$ atau sama dengan

$Y=12,616+0,534 X_{1}+1,054 X_{2}+1,174 X_{3}$.

Berdasarkan nilai parsial dapat dilihat bahwa jumlah bunga dipengaruhi oleh $45,3 \%$ waktu muncul ulat, $3,8 \%$ jumlah ulat dan $25,6 \%$ tingkat serangan. 
Tabel 3 Hasil analisis korelasi dan regresi waktu muncul ulat, jumlah ulat, dan tingkat serangan terhadap jumlah bunga

\begin{tabular}{lcccccc}
\hline Parameter & \multicolumn{4}{c}{ Determinasi } & Parsial & $R$ \\
\cline { 2 - 4 } & $\mathrm{B}_{0}$ & $\mathrm{~B}_{1}$ & $\mathrm{~B}_{2}$ & $\mathrm{~B}_{3}$ & & 0,507 \\
Konstanta & 2,535 & & & & 0,453 & \\
Waktu muncul ulat & & 0,534 & & & 0,038 & \\
Jumlah ulat & & & 0,053 & & 0,256 & \\
Tingkat serangan & & & & 0,160 & 0,250 \\
\hline
\end{tabular}

Analisis korelasi antara regresi jumlah ulat, tingkat serangan, dan jumlah bunga dengan jumlah biji menunjukkan nilai $R$ sebesar 0,728 yang menunjukkan hubungan yang kuat. Persamaan regresi untuk hubungan waktu muncul ulat, jumlah ulat, dan jumlah bunga dengan jumlah biji adalah $L N Y=2,533+\left(0,024 \operatorname{Ln} X_{1}\right)+0,191 \operatorname{Ln} X_{2}+0,474 \operatorname{Ln} X_{3} \quad$ atau $Y=0,079+0,976 X_{1}+1,210 X_{2}+1,606 X_{3}$.

Tabel 4 Hasil analisis korelasi dan regresi jumlah ulat, tingkat serangan, dan jumlah bunga terhadap jumlah biji Parameter Determinasi

Berdasarkan nilai parsial dapat diketahui bahwa jumlah biji dipengaruhi oleh $4 \%$ jumlah ulat, $18,3 \%$ tingkat serangan, dan $67,6 \%$ jumlah bunga. Berdasarkan nilai parsial dapat diketahui bahwa jumlah biji dipengaruhi oleh $4 \%$ jumlah ulat, $18,3 \%$ tingkat serangan, dan $67,6 \%$ jumlah bunga.

\begin{tabular}{lrrrrr}
\cline { 2 - 5 } & $B_{0}$ & $B_{1}$ & $B_{2}$ & $B_{3}$ & 0,728
\end{tabular}

Jumlah ulat

$-0.240$

0,040

$\begin{array}{lll}\text { Tingkat serangan } & 0,191 & 0,183\end{array}$

Jumlah bunga

$0,474 \quad 0,676$

Hasil penelitian sesuai dengan Suriana (2011) yang menyatakan bahwa $C$. trifenestrata memakan daun tanaman muda maupun tua sampai habis. Kerusakan pada tanaman (bersifat defoliator) dapat memicu pertumbuhan generatif, sebab tanaman terpicu untuk menghasilkan pucuk baru hanya dalam waktu sekitar dua minggu saja, selanjutnya setelah tanaman menjadi gundul, maka munculnya bunga dan buah lebih cepat, sehingga adanya serangan ulat ini justru dapat menguntungkan bagi tanaman.

Serangan ulat kipat dapat mengurangi jumlah daun yang terdapat pada tanaman, sehingga dapat meningkatkan $\mathrm{C} / \mathrm{N}$ rasio. Yulianto et al. (2008) nilai $\mathrm{C} / \mathrm{N}$ rasio yang tinggi mengakibatkan penumpukan karbohidrat yang akhirnya merangsang pembentukan bunga dan buah. Ulat kipat menyerang pada bagian pucuk tanaman sehingga dapat menyebabkan pembentukan tunas pada tanaman menjadi terhambat. Saprudin (2013) menyatakan bahwa dalam fase generatif terjadi penumpukan karbohidrat pada bagian seperti kuncup bunga, bunga, buah, biji, maupun umbi. Pembentukan tunas atau cabang baru berarti terjadi pemakaian sebagian dari karbohidrat yang berakibat dapat mengurangi jumlah bunga yang terbentuk, sehingga adanya hambatan pada pembentukan tunas baru inilah yang dapat meningkatkan pembentukan bunga.

\section{KESIMPULAN DAN SARAN}

\section{Kesimpulan}

Kesimpulan dari hasil penelitian Hubungan Tingkat Serangan Ulat Kipat Cricula trifenestrata Helfer terhadap Hasil Mete adalah :

1. Jumlah rata-rata ulat yang menyerang setiap pucuk tanaman adalah 5,51 dengan jumlah ulat rata-rata terendah 0,5 dan jumlah rata-rata tertinggi adalah 12.

2. Jumlah rata-rata tangkai bunga adalah 2,5 dengan jumlah tangkai bunga tertinggi 5,17 dan jumlah tangkai terendah 1 . Jumlah bunga rata-rata setiap pucuk adalah 14,99 dengan jumlah bunga terendah adalah 4.

3. Jumlah bunga dipengaruhi oleh $45,3 \%$ waktu muncul ulat, $3,8 \%$ jumlah ulat dan $25,6 \%$ tingkat serangan. Jumlah biji dipengaruhi oleh $4 \%$ jumlah ulat, $18,3 \%$ tingkat serangan, dan $67,6 \%$ jumlah bunga.

4. Persamaan regresi untuk hubungan waktu muncul ulat, jumlah ulat, dan tingkat serangan ulat dengan jumlah bunga adalah $Y=12,616+0,534 X_{1}+1,054 X_{2}+1,174 X_{3}$ sedangkan persamaan regresi untuk hubungan waktu muncul ulat, jumlah ulat, dan tingkat serangan ulat dengan jumlah bunga adalah $Y=0,079+0,976 X_{1}+1,210 X_{2}+1,606 X_{3}$. 


\section{Saran}

Ulat kipat yang menyerang pada tanaman mete tidak dapat dikategorikan sebagai hama karena dapat meningkatkan hasil buah mete, sehingga petani mete sebaiknya tidak memberantas ulat kipat yang menyerang tanaman mete dan sebaiknya dapat mengelola ulat kipat tersebut karena kokon ulat kipat mempunyai nilai ekonomi yang dapat menambah penghasilan petani.

\section{DAFTAR PUSTAKA}

[BPS] Badan Pusat statistika. 2014. Potensi jambu mete di kabupaten Wonogiri. http://www.wonogirikab.bps.go.id. Diakses 25 November 2016.

Ahmed SA, Dutta LC, Sarnah MC. 2012. Bio-efficacy of some insecticides against leaf eating caterpillar Helfer (Lepidoptera: Saturniidae) infesting some Persea bombyci. Acad J Entomol. 5(2):94-98 DOI:10.5829/idosi.aje.2012.5.2.6411.

Amin MR, Ahad M, Rono MA, Tithi DA. 2008. Life history traits of Cricula trifenestrata (lepidoptera: Saturniidae) feeding on Mangifera indica. J Agrofor Environ. 2(1):1-6.

Assogwa EU, Anikwe JC, Ndubuaku TCN, Okelana FA. 2009. Distribution and damage characteristics of an emerging insect pest of cashew, Plocaederus ferrugineus L. (Coleoptera: Cerambycidae) in Nigeria: a preliminary report. African Journal of Biotechnology. 8(1):53-58.

Balogoun I, Leonard EA, Allou S et al. 2016. Effect of climate factors on cashew (Annacardium occidentale L.) productivity in Benin (West Africa). J Earth Sci Clim Change. 7(1):1-10 DOI:10.4172/21577617.1000329.

Chen F, David P, Fritz V. 2012. Structure and physical properties of silkworm cocons. J Royal Society. 1(1):2299-2308.

Daras U, Pitono J. 2006. Pengaruh pemupukan terhadap pertumbuhan dan produksi jambu mete di Lombok. J Littri. 12(1):20-26.

Ditjenbun. 2015. Produktivitas jambu mete menurut provinsi di Indonesia. Http://ditjenbun.pertanian.go.id.Diakses 25 November 2016.

Hammed LA, Lawal BA, Kolapo KA. 2011. Growth and nutrient uptake of cashew (annacardium occidentale L.) seedlings as effected by nut-size in the nursery. $J$ Agriculture Research. 6(17):3962-3971.

Karmawati E. 2008. Perkembangan jambu mete dan strategi pengendalian hama utamanya. J Perspektif. 7(2):102-111.

Listyati D, Sudjarmoko B. 2011. Nilai tambah ekonomi pengolahan jambu mete indonesia. $\mathrm{J}$ Ristri. 2(2):231-238.

Redaksi trubus. 2007. Menjadikan buah lebih manis. Jakarta(ID): Wisma Hijau.

Rono MMA, Ahad MA, Hasan S, Uddin MF, Islam AKMN. 2008. Morphometrics measurement of mango defoliator Cricula trifenestrata ( $F$. Lepidoptera : Saturniidae). J Sustain Crop Prod. 3(3):45-48.

Saprudin. 2013. Pengaruh umur tanaman pada saat pemangkasan terhadap pertumbuhan dan hasil mentimun (Cucumis sativus L.). J Juristek. 1(2):5162.

Scaven VL, Nicole ER. 2013. Physiological effects of climate warming on flowering plants and insect pollinators and potential consequense for their interactions. J Curr Zool. 59(3):418-426.

Soesanthy F dan Trisawa IM. 2011. Pengelolaan serangga-serangga yang berasosiasi dengan tanaman jambu mete. J Ristri. 2(2):221-230.

Suriana. 2011. Morfometri dan keragaan genetik ulat sutera liar Cricula trifenestrata Helfer (Lepidoptera: Saturniidae). Disertasi Progam Pasca Sarjana. Institut Pertanian Bogor.

Thamrin M, Slamet S, Edi S. 2009. Efektivitas strangulasi terhadap pembungaan tanaman jeruk pamelo "cikoneng" (Citrus grandis (L.)Osbeck) pada tingkat beban buah sebelumnya yang berbeda. $J$ Agron Indonesia. 37(1):40-45.

Tikader A, Kunjupillai V, Beera S. 2014. Cricula trifenestrata (Helfer) (Lepidoptera: Saturniidae) - a silk producing wild insect in India. J Trop Lepid Res. 24(1):22-29.

Tikader A. 2012. New record of Brachymeria tibialis (Walker) (Hymenoptera: Chalcididae) on Cricula trifenestrata (Helfer) from India. J Mun Ent Zool. 7(1):222-225.

Wibowo IH, Okid PA, Agung B 2004. Pengaruh suhu dan fotoperiode terhadap telur ulat sutera emas (Cricula trifenestrata Helf.). J BioSmart. 6(1):71-74 ISSN 1411-321X.

Yulianto, J Susilo, D Juanda. 2008. Keefektifan teknik perangsangan pembungaan pada kelengkeng. J Hort. 18(2):148-154.

Yu-Rong $\mathrm{H}$, Lu L, Kuang Z, Feng $\mathrm{X}$, Chen $\mathrm{H}, \mathrm{Wu} \mathrm{Y}$ 2005. Effect of temperature and humadity on the virulence of beetle-derived Beauveria bassiana (Balsamo) vuillemin (Deuteromycetes: Moniliales) against the daikon leaf beetle, Phaedon brassicae Baly (Coleoptera: Chrysomelidae). J Acta Entomologica Sinica. 48(5):679-686 ISSN 04546296. 